\title{
Update on HPLC and FPLC analysis of nitrogen compounds in dairy products
}

\author{
D Gonzalez-Llano, C Polo, M Ramos * \\ Inst $^{\circ}$ de Fermentaciones Industriales CSIC C/ Juan de la Cierva, 3.- 28006 Madrid, Spain
}

(Received 9 October 1989; accepted 12 March 1990)

\begin{abstract}
Summary - HPLC and FPLC methods for the analysis of proteins, peptides, amino acids and amines in dairy products, as well as their ability to resolve practical difficulties, are reviewed. The most pertinent literature is summarized in tables giving the chromatographic conditions used in the analysis and the main objectives of each reference.
\end{abstract}

HPLC / FPLC / dairy product / casein / whey protein / peptide / amino acid / nitrogen compound

Résumé - L'analyse HPLC et FPLC des composés azotés dans les produits laitiers (synthèse). Cet article est une revue bibliographique concernant les méthodes HPLC et FPLC utilisées pour l'analyse des protéines, des peptides, des acides aminés et des amines dans les produits laitiers. Une analyse critique de l'intérêt de ces méthodes pour la résolution de problèmes pratiques a également été abordée. Les références citées dans l'article ont été résumées sous forme de tableaux donnant les conditions chromatographiques utilisées et les objectifs de chaque étude.

HPLC / FPLC / produit laitier / caséine / lactosérum / peptide / acide aminé / matière azotée

\section{INTRODUCTION}

The nitrogen fraction in dairy products is of great interest in relation to nutritional, biological and technical aspects.

Fast, specific methods of analysis have been developed in response to high dairy production rates and the need for stringent analytical quality controls. Versatility, short analysis time, effective separation, high resolution, and adaptability to automatic procedures have made high performance liquid chromatography (HPLC) one of the basic techniques employed in the dairy sector.

Fast protein liquid chromatography (FPLC), a technique developed for the purification of proteins in their native state, has become an increasingly useful tool in the dairy sector. Since, FPLC only needs a relatively low backpressure to drive the high rates of flow at which the separations are performed, the risk of denaturation caused by shearing forces diminishes. Moreover, the mechanical components are resistent to corrosive buffer and there is no contamination or inactivation of the compounds of interest.

\footnotetext{
* Correspondence and reprints
} 
The present paper reviews HPLC applications in the study of proteins, peptides, amino acids and amines, and FPLC applications in the study of proteins in dairy products. Their practical repercussions (detection of mixtures, study of proteolysis, and the like) are also considered.

\section{Analysis of proteins}

A number of techniques have been used to separate and analyze milk proteins: salt and organic solvent fractionation (McKenzie, 1971), starch gel electrophoresis (Aschaffenburg and Michalak, 1968), polyacrylamide gel electrophoresis (Andrews, 1981) isoelectric focussing (Trieu-Cuot and Gripon, 1981), as well as combinations thereof. lon-exchange chromatography on DEAE cellulose and open-column gel permeation have been widely used, but the most significant advances have been achieved by applying high performance liquid chromatographic and fast protein liquid chromatographic techniques.

These techniques reduce analysis times from days or even weeks to just hours. HPLC and FPLC methods are also useful in isolating compounds present in small concentrations, and the separations carried out on a laboratory scale can be transferred to an industrial scale.

Practically all known mechanisms have been employed in the separation of proteins by chromatography, ie, separations based on molecule size (gel permeation chromatography), on charge (ionexchange chromatography), on hydrophobicity (reversed phase chromatography and hydrophobic interaction chromatography), and even on combinations of these various mechanisms.

Table I summarizes the main papers in which HPLC and FPLC were applied to the study of proteins in milk products.

\section{Caseins}

Whole casein is an extremely complex mixture containing a number of fractions. Schlossberger (1846) separated casein into 2 fractions. The development of electrophoresis enabled Mellander (1939) to identify 3 components $(\alpha, \beta$, and $\gamma)$. Waugh and Von Hippel (1956) showed that the $\alpha$ fraction could be further separated into K-casein and the $\alpha_{\mathrm{s}}$ fraction. Starch gel electrophoresis with urea was used by Wake and Baldwin (1961) to detect over 20 components in whole casein.

Various methods have been applied to casein analysis: polyacrylamide gel electrophoresis (PAGE) is undoubtedly the most common, but, in view of recent advances in HPLC and FPLC technology, these latter methods may be an alternative to PAGE in the study of caseins.

The molecular weights of the different casein fractions being quite similar, casein separation by gel permeation chromatography is unsatisfactory. Dimenna and Segall (1981) used 2 columns in series (a TSK125 Toyo Soda 2000 SW column and a MicroPak TSK 3000 SW column) with molecular weight limits of 100000 and larger than $350000 \mathrm{Da}$, respectively. To separate the caseins from skim milk, elution was made with $0.05 \mathrm{~mol}^{-1} \mathrm{l}^{-1}$ phosphate buffer ( $\mathrm{pH} 6.8$ ) containing 0.1 molel-1 $^{-1}$ sodium sulphate. $\alpha_{\mathrm{s} 1}$ and $\beta$ caseins were eluted in a first peak, and the rest of the caseins along with $\mathrm{BSA}$ and $\mathrm{I}_{\mathrm{g}} \mathrm{G}$ were eluted in a second peak, while a third peak consisted mainly of $\beta$ lactoglobulins along with contamination of $\alpha_{s 1}$ and $\beta$ caseins. Peak 4 contains only $\alpha$-lactalbumin. According to the authors, separation of bovine skim milk proteins is highly dependent on sample size, a $10 \mu \mathrm{l}$ vs $30 \mu \mathrm{l}$ injection volume resulted in a better separation of casein from whey proteins and IgG from BSA. The results reported by Haasnoot et al (1987) on 
caseins were not much better. They also employed 2 columns (a TSK 3000 SW column and a TSK $2000 \mathrm{SW}$ column) in series with a 0.1 moløl-1 $\mathrm{Na}_{2} \mathrm{SO}_{4}+0.02$ mol. I $^{-1} \mathrm{NaH}_{2} \mathrm{PO}_{4}, \mathrm{pH} 6.8$ buffer and used 6 mol. $^{-1}$ urea to dissolve the caseins. Alpha $_{\mathrm{s} 1}$ and $\beta$-caseins and their breakdown products, ie $\alpha_{\mathrm{s} 1}-\mathrm{I}$ and $\gamma$-caseins were eluted in the first peak; the second peak contains several components among which 2 could be $\gamma_{2}$ and $\gamma_{3}$ casein, which are breakdown products of $\beta$-casein. Both Haasnoot et al (1987) and Dimenna and Segall (1981) used PAGE for peak identification.

Better results can be achieved using ion-exchange chromatography. Since, the isoelectric points for the main milk proteins lie between 4.5 and 5.5 , except for para-Kcasein ( $\mathrm{pl}=9.4$ ), they can be fractionated on anionic columns at a pH above 5.5 or on cationic columns at lower $\mathrm{pH}$ levels. Andrews et al (1985), using a Mono S $\mathrm{CHR} / 5 / 5$ cationic FPLC column with $\mathrm{pH}$ 3.2-3.8 buffers, separated caseins, but the results were somewhat less satisfactory than those obtained on anionic columns.

Both the TSK-DEAE-5PW and Mono $Q$ HR 5/5 anionic columns (Humphrey and Newsome, 1984) yield better separations than those obtained on DEAE-cellulose (Mercier et al, 1968) with much shorter analysis time ( $1 \mathrm{~h}$ for TSK columns and 25 min for Mono Q HR $5 / 5$ columns, compared to about $20 \mathrm{~h}$ for conventional DEAE-cellulose columns). In all cases the buffer was Tris $\mathrm{HCl}$ or imidazol at a $\mathrm{pH}$ of 7-8 and a concentration between 4.5 mol. $1^{-1}$ and 8 mol..$^{-1}$ urea. The elution was obtained with a linear gradient of $\mathrm{NaCl}$. Casein samples are normally dissolved in the initial solvent, after addition of dithioerythritol (DTT) or 2-mercaptoethanol (MCE) to achieve dissociation and to prevent casein aggregation.

Using these conditions, Andrews et al (1985) and Guillou et al (1987) separated
5 or $6 \mathrm{~K}$-casein components in addition to the $\alpha_{s 1}, \alpha_{s 2}, \alpha_{s 0}$ and $\beta$-caseins.

Using a Mono Q HR 5/5 column, Guillou et al (1987) succeeded in separating the $\beta$ $C$ variant from the other variants of $\beta$ casein $\left(A_{1}, A_{2}\right.$ and $\left.B\right)$ and K-casein variants $A$ and $B$ (fig 1). The method proposed by these authors is linear, repeatable and allows the quantification of bovine caseins.

Satisfactory casein separations have also been performed using reversed-phase chromatography (Barrefors et al, 1985; Visser et al, 1986; Mikkelsen et al, 1987).

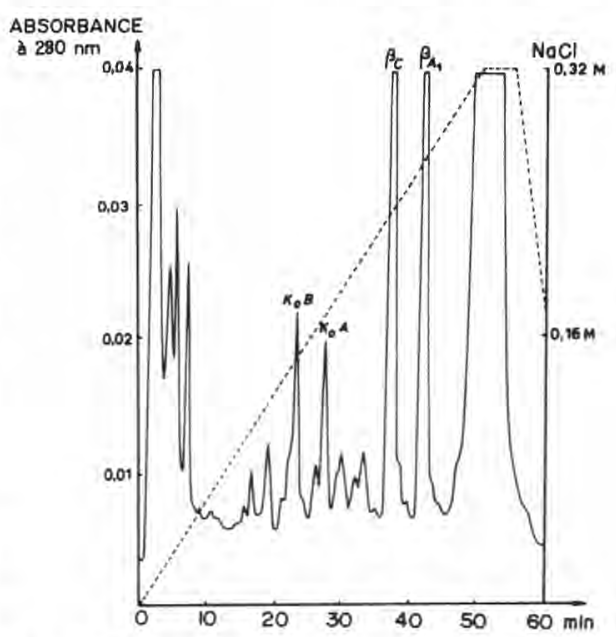

Fig 1. FPLC separation of caseins genetic variants on the Mono $Q$ column. The sample of whole casein (k-A-k-B; $\beta-C-\beta-A 1 ; \alpha_{s 2}-A ; \alpha_{s 1}-A$ ) dissolved in a $5.10^{-3} \mathrm{~mol}^{-1} \mathrm{Tris}-\mathrm{HCl} ; 4.5$ mol-1-1 urea buffer $\mathrm{pH} 8.0$ + dithiothreitol $\left(8.10^{-4}\right.$ molor ${ }^{-1}$ ) was applied on the column and eluted at a flow rate of $1 \mathrm{ml} / \mathrm{min}$ using a $0-0.32 \mathrm{~mol} / \mathrm{l}^{-1}$ $\mathrm{NaCl}$ gradient. Temperature: $40^{\circ} \mathrm{C}$. [From Guillou et al (1986), Lait 67, 135 with permission].

Séparation par FPLC sur colonne Mono $Q$ de la caséine entière d'une vache hétérozygote: $k-A-$ $k-B ; \beta-C-\beta-A 1 ; \alpha_{s 2}-A ; \alpha_{s 1}-A$. Débit $1 \mathrm{ml} / \mathrm{min}$; température $40^{\circ} \mathrm{C}$. Tampon Tris- $\mathrm{HCl} 5.10^{-3}$ mol. ${ }^{-1}$; urée $4,5 \mathrm{~mol}^{-1}$; dithiothréitol $6,4 \cdot 10^{-5}$ mol. $\mathrm{H}^{-1} ; \mathrm{pH}$ 8.0. Elution par un gradient de $\mathrm{NaCl}$ de 0 à $0,32 \mathrm{~mol}^{-1}$. Echantillon dans le tampon avec dithiothréitol $8 \cdot 10^{-4} \mathrm{~mol} \cdot \mathrm{r}^{-1}$. 
Table I. HPLC application to the analysis of proteins in dairy products.

Application de la CLHP au dosage des protéines dans les produits laitiers.

\begin{tabular}{|c|c|c|c|c|c|c|}
\hline \multirow{2}{*}{ Stationary phase } & \multirow{2}{*}{ Eluent } & \multicolumn{3}{|c|}{ Chromatographic } & \multirow{2}{*}{ Objective } & \multirow{2}{*}{ Reference } \\
\hline & & Detection & mode & Separation of: & & \\
\hline $\begin{array}{l}\text { Synchropac } \\
\text { GPC-100 } \\
\text { HP-RP-8 }\end{array}$ & $\begin{array}{l}0.05 \mathrm{M} \text {-Tris pH } 6.0 \text {, } \\
0.2 \mathrm{M}-\mathrm{NaCl} \\
\text { a) } 0.5 \mathrm{M}^{-} \mathrm{KH}_{2} \mathrm{PO}_{4} \text { : } \\
2-\mathrm{Methoxyethanol} \\
\text { (98:2), } \mathrm{pH} 2 \\
\text { b) Isopropanol: } 2 \text { - } \\
\text { Methoxyethanol (98:2) }\end{array}$ & $280 \mathrm{~nm}$ & $\begin{array}{l}\text { Size } \\
\text { exclusion } \\
\text { reversed } \\
\text { phase }\end{array}$ & $\begin{array}{l}\text { Whey proteins } \\
\text { BSA, } \alpha-1 \mathrm{la}, \beta-\mathrm{lg}\end{array}$ & $\begin{array}{l}\text { Separation of } \\
\text { whey proteins }\end{array}$ & Diosady et al (1980) \\
\hline $\begin{array}{l}\text { TSK-125 + } \\
\text { Micropak TSK } \\
3000 \text { SW }\end{array}$ & $\begin{array}{l}0.05 \mathrm{M}-\text { Phosphate buffer } \\
\mathrm{pH} 6.8,0.1 \mathrm{M}-\mathrm{Na}_{2} \mathrm{SO}_{4}\end{array}$ & $280 \mathrm{~nm}$ & $\begin{array}{l}\text { Size } \\
\text { exclusion }\end{array}$ & $\begin{array}{l}\text { Caseins and } \\
\text { Whey proteins }\end{array}$ & $\begin{array}{l}\text { Separation of } \\
\text { milk proteins }\end{array}$ & $\begin{array}{l}\text { Dimenna and } \\
\text { Segall (1981) }\end{array}$ \\
\hline $\begin{array}{l}\text { Micropak TSK } \\
3000 \text { SW }\end{array}$ & $\begin{array}{l}0.04 \mathrm{M}-\text { TRIS HCl } \\
\mathrm{pH} 7.6,0.05 \mathrm{M}-\mathrm{NaCl}\end{array}$ & $220 \mathrm{~nm}$ & $\begin{array}{c}\text { Size } \\
\text { exclusion }\end{array}$ & Milk proteins & $\begin{array}{l}\text { Separation of } \\
\text { milk proteins }\end{array}$ & $\begin{array}{l}\text { Bican and Blanc } \\
\text { (1982) }\end{array}$ \\
\hline Spherisorb S5 C6 & $\begin{array}{l}\text { a) } 0.15 \mathrm{M}-\mathrm{NaCl}-\mathrm{HCl} \\
\mathrm{pH} 2.1 \mathrm{~b}) \mathrm{CH}_{3} \mathrm{CN}\end{array}$ & $210 \mathrm{~nm}$ & $\begin{array}{l}\text { Reversed } \\
\text { phase }\end{array}$ & Whey proteins & $\begin{array}{l}\text { Separation of } \\
\text { whey proteins }\end{array}$ & Pearce (1983) \\
\hline $\begin{array}{l}\text { Toyo-Soda TSK } \\
3000 \text { SW }\end{array}$ & $\begin{array}{l}\text { 0.1 M-Phosphate buffer } \\
\text { pH } 6.8,0.05 \mathrm{M}-\mathrm{NaCl} \text {, } \\
0.02 \% \mathrm{NaN}_{3} \\
0.1 \mathrm{M}-\mathrm{Phosphate} \text { buffer } \\
\text { pH } 6.8,0.1 \% \text { SDS }\end{array}$ & $280 \mathrm{~nm}$ & $\begin{array}{c}\text { Size } \\
\text { exclusion }\end{array}$ & Proteins & $\begin{array}{l}\text { Separation of } \\
\text { native proteins } \\
\text { Separation of } \\
\text { denatured proteins }\end{array}$ & Gupta (1983) \\
\hline $\begin{array}{l}\text { TSK-DEAE-5 PW } \\
\text { Mono Q HR 5/5 }\end{array}$ & $\begin{array}{l}\text { a) } 0.02 \mathrm{M} \text {-TRIS-HCl, } \\
4.5 \mathrm{M} \text {-urea, } \mathrm{pH} 8 \\
\text { b) Idem a) } 0.5 \mathrm{M}-\mathrm{NaCl} \\
\text { a) Several buffer systems } \\
\text { b) Idem a) }+0.5 \mathrm{M}-\mathrm{NaCl}\end{array}$ & $280 \mathrm{~nm}$ & $\begin{array}{c}\text { Anion } \\
\text { exchange }\end{array}$ & $\begin{array}{l}\text { Caseins } \\
\text { Whey proteins }\end{array}$ & $\begin{array}{l}\text { Fractionation of } \\
\text { caseins and whey } \\
\text { proteins }\end{array}$ & $\begin{array}{l}\text { Humphrey and } \\
\text { Newsome (1984) }\end{array}$ \\
\hline
\end{tabular}




\begin{tabular}{|c|c|c|c|c|c|c|}
\hline \multirow[b]{2}{*}{ Stationary phase } & \multirow[b]{2}{*}{ Eluent } & \multicolumn{3}{|c|}{ Chromatographic } & \multirow[b]{2}{*}{ Objective } & \multirow[b]{2}{*}{ Reference } \\
\hline & & Detection & mode & Separation of: & & \\
\hline $\begin{array}{l}\text { Micropak TSK } \\
3000 \mathrm{SW}\end{array}$ & $\begin{array}{l}0.04 \mathrm{M}-\mathrm{TRIS}-\mathrm{HCl}, \\
0.05 \mathrm{M}-\mathrm{NaCl}, \mathrm{pH} 7.4\end{array}$ & $220 \mathrm{~nm}$ & $\begin{array}{c}\text { Size } \\
\text { exclusion }\end{array}$ & Whey proteins & $\begin{array}{l}\text { Evaluation of } \\
\text { heat treatment }\end{array}$ & $\begin{array}{l}\text { Kneifel and Ulberth } \\
\text { (1985) }\end{array}$ \\
\hline Mono Q HR 5/5 & $\begin{array}{l}\text { a) } \mathrm{H}_{2} \mathrm{O} \\
\text { b) } 0.7 \mathrm{M} \text {-Sodium acetate, } \\
\text { pH } 6.3\end{array}$ & $280 \mathrm{~nm}$ & $\begin{array}{c}\text { Anion } \\
\text { exchange }\end{array}$ & Whey proteins & $\begin{array}{l}\text { Evaluation of } \\
\text { heat treatment }\end{array}$ & $\begin{array}{c}\text { Manji and Kakuda } \\
(1986)\end{array}$ \\
\hline Mono S HR 5/5 & $\begin{array}{l}0.05 \mathrm{M} \text {-Sodium formate } \\
\mathrm{pH} 3.8,8 \mathrm{M} \text {-Urea, } \\
0.01 \mathrm{M} \text {-2-Mercapotethanol } \\
\text { (0-0.03 } \mathrm{M}-\mathrm{NaCl} \text { gradient) }\end{array}$ & $280 \mathrm{~nm}$ & $\begin{array}{l}\text { Cation } \\
\text { exchange }\end{array}$ & Caseins & $\begin{array}{l}\text { Separation of } \\
\text { milk proteins }\end{array}$ & Andrews et al (1985) \\
\hline \multirow[t]{2}{*}{ Mono Q HR 5/5 } & $\begin{array}{l}0.02 \mathrm{M}-\mathrm{TRIS}-\mathrm{HCl} \mathrm{pH} 7.0 \\
4.5 \mathrm{M} \text {-Urea } \\
0.01 \mathrm{M}-2-\mathrm{Mercaptoethanol} \\
(0-0.35 \mathrm{M}-\mathrm{NaCl} \text { gradient) }\end{array}$ & & $\begin{array}{c}\text { Anion } \\
\text { exchange }\end{array}$ & Caseins & & \\
\hline & $\begin{array}{l}0.02 \mathrm{M}-\mathrm{TR} \mathrm{IS}-\mathrm{HCl} \mathrm{pH} 7.0 \\
\text { (0-0.35 M-NaCl gradient) }\end{array}$ & & & Whey proteins & & \\
\hline $\begin{array}{l}\text { Superose } 12 \\
\mathrm{Hr} 10 / 30\end{array}$ & $\begin{array}{l}0.1 \mathrm{~m}-\mathrm{TRIS}-\mathrm{HCl} \mathrm{pH} 7.0 \\
0.5 \mathrm{M}-\mathrm{NaCl}, 0.01 \mathrm{M}-\mathrm{NaN}_{3}\end{array}$ & & $\begin{array}{c}\text { Size } \\
\text { exclusion }\end{array}$ & Whey proteins & & \\
\hline Mono Q HR 5/5 & $\begin{array}{l}3.3 \mathrm{M} \text {-Urea, } 0.01 \\
\text { M-Imidazole pH } 7.0 \\
\text { (0-0.3 } \mathrm{M}-\mathrm{NaCl} \text { gradient) }\end{array}$ & $280 \mathrm{~nm}$ & $\begin{array}{c}\text { Anion } \\
\text { exchange }\end{array}$ & Caseins & $\begin{array}{l}\text { Analysis of different } \\
\text { forms of K-Casein }\end{array}$ & Dalgleish (1985) \\
\hline C8 HR 5/10 & $\begin{array}{l}\text { a) } 0.1 \% \text { TFA in } \\
30 \% \mathrm{CH}_{3} \mathrm{CN} \\
\text { b) } 0.1 \% \text { TFA in } \\
48 \% \mathrm{CH}_{3} \mathrm{CN}\end{array}$ & $280 \mathrm{~nm}$ & $\begin{array}{l}\text { Reversed } \\
\text { phase }\end{array}$ & Caseins & $\begin{array}{l}\text { Separation of } \\
\text { caseins }\end{array}$ & $\begin{array}{c}\text { Barrefors et al } \\
(1985)\end{array}$ \\
\hline
\end{tabular}




\begin{tabular}{|c|c|c|c|c|c|c|}
\hline \multirow[b]{2}{*}{ Stationary phase } & \multirow[b]{2}{*}{ Eluent } & \multicolumn{3}{|c|}{ Chromatographic } & \multirow[b]{2}{*}{ Objective } & \multirow[b]{2}{*}{ Reference } \\
\hline & & Detection & mode & Separation of : & & \\
\hline Mono Q Hr 5/5 & $\begin{array}{l}0.01 \mathrm{M} \text {-Imidazole-HCl } \\
\mathrm{pH} 7.0,3.3 \mathrm{M} \text {-Urea } \\
0.01 \mathrm{M}-2-\mathrm{Mercaptoethanol} \\
(0-0.5 \mathrm{M}-\mathrm{NaCl} \text { gradient) }\end{array}$ & & $\begin{array}{l}\text { Anion } \\
\text { exchange }\end{array}$ & Caseins & $\begin{array}{l}\text { Separation of } \\
\text { caseins }\end{array}$ & $\begin{array}{l}\text { Barrefors et al } \\
\text { (1985) }\end{array}$ \\
\hline $\begin{array}{l}\text { Protein PAK } \\
\text { DEAE-5 PW }\end{array}$ & $\begin{array}{l}0.02 \mathrm{M}-\mathrm{TR} I \mathrm{~S}-\mathrm{HCl}, \mathrm{pH} 7.2 \\
\text { (0-0.5 M-NaCl gradient) }\end{array}$ & $280 \mathrm{~nm}$ & $\begin{array}{c}\text { Anion } \\
\text { exchange }\end{array}$ & $\begin{array}{l}\text { Caseins and } \\
\text { whey proteins }\end{array}$ & $\begin{array}{l}\text { Separation of } \\
\text { milk proteins }\end{array}$ & Bican (1985) \\
\hline Bio-Gel HP HT & $\begin{array}{l}\text { a) } 0.005 \mathrm{M}-\mathrm{KH}_{2} \mathrm{PO}_{4}, \\
6 \mathrm{M} \text {-Urea, } 600 \mu \mathrm{M}-\mathrm{CaCl}_{2} \\
\text { pH } 6.8 \mathrm{~b}) 0.4 \mathrm{M}-\mathrm{KH}_{2} \mathrm{PO}_{4} \text {, } \\
6 \mathrm{M} \text {-Urea, } 7 \mu \mathrm{m}-\mathrm{CaCl}_{2}, \\
\text { pH } 6.8\end{array}$ & $280 \mathrm{~nm}$ & $\begin{array}{c}\text { Mixed } \\
\text { mechanism }\end{array}$ & Caseins & $\begin{array}{l}\text { Separation of } \\
\text { milk proteins }\end{array}$ & Visser et al (1986) \\
\hline $\begin{array}{l}\text { Bio-Gel } \\
\text { TSK-DEAE } \\
5 \text { PW }\end{array}$ & $\begin{array}{l}0.005 \mathrm{M}-\mathrm{TRIS}-\mathrm{HCl} \mathrm{pH} \mathrm{8,2,} \\
4 \mathrm{M}-\mathrm{Urea}, 0.03 \mathrm{M}-\mathrm{NaCl} \\
(0.028-0.28 \mathrm{M}-\mathrm{NaCl} \\
\text { gradient) }\end{array}$ & & $\begin{array}{c}\text { Anion } \\
\text { exchange }\end{array}$ & & & \\
\hline Hi-Pore RP-318 & $\begin{array}{l}\text { a) } 0.1 \% \text { TFA in } \\
10 \% \mathrm{CH}_{3} \mathrm{CN} \\
\text { b) } 0.1 \% \text { TFA in } \\
90 \% \mathrm{CH}_{3} \mathrm{CN}\end{array}$ & & $\begin{array}{l}\text { Reversed } \\
\text { phase }\end{array}$ & & & \\
\hline $\begin{array}{l}\text { Bio-Gel TSK } \\
\text { Phenyl RP }\end{array}$ & $\begin{array}{l}\text { a) } 0.1 \% \text { TFA in } \\
10 \% \mathrm{CH}_{3} \mathrm{CN} \\
\text { b) } 0.1 \% \text { TFA in } \\
90 \% \mathrm{CH}_{3} \mathrm{CN}\end{array}$ & & $\begin{array}{l}\text { Reversed } \\
\text { phase }\end{array}$ & & & \\
\hline Mono Q Hr 5/5 & $\begin{array}{l}0.02 \mathrm{M}-\mathrm{TR} \mathrm{IS}-\mathrm{HCl} \\
\text { pH } 8.5,6 \mathrm{M}-\text { Urea } \\
\text { (0-1 } \mathrm{M}-\mathrm{NaCl} \text { gradient) }\end{array}$ & $280 \mathrm{~nm}$ & $\begin{array}{l}\text { Anion } \\
\text { exchange }\end{array}$ & Caseins & $\begin{array}{l}\text { To detect mixtures } \\
\text { of milk }\end{array}$ & $\begin{array}{l}\text { Haasnoot et al } \\
\text { (1986 a) }\end{array}$ \\
\hline
\end{tabular}




\begin{tabular}{|c|c|c|c|c|c|c|}
\hline \multirow[b]{2}{*}{ Stationary phase } & \multirow[b]{2}{*}{ Eluent } & \multicolumn{3}{|c|}{ Chromatographic } & \multirow[b]{2}{*}{ Objective } & \multirow[b]{2}{*}{ Reference } \\
\hline & & Detection & mode & Separation of : & & \\
\hline $\begin{array}{l}\text { TSK } 3000 \text { SW + } \\
\text { TSK } 2000 \text { SW }\end{array}$ & $\begin{array}{l}0.1 \mathrm{M}-\mathrm{Na}_{2} \mathrm{SO}_{4}, \\
0.02 \mathrm{M}-\mathrm{NaH}_{2} \mathrm{PO}_{4}, \\
\mathrm{pH} 6.8\end{array}$ & $280 \mathrm{~nm}$ & $\begin{array}{c}\text { Size } \\
\text { exclusion }\end{array}$ & Immunoglobulin G & $\begin{array}{l}\text { Detection of } \\
\text { colostrum in milk }\end{array}$ & $\begin{array}{l}\text { Haasnoot et al } \\
\quad(1986 \mathrm{~b})\end{array}$ \\
\hline Mono S Hr 5/5 & $\begin{array}{l}0.01 \mathrm{M}-\mathrm{Im} \text { idazole- } \mathrm{HCl} \\
\mathrm{pH} 7.0, \\
(0-1 \mathrm{M}-\mathrm{NaCl} \text { gradient) }\end{array}$ & $280 \mathrm{~nm}$ & $\begin{array}{c}\text { Cation } \\
\text { exchange }\end{array}$ & $\begin{array}{l}\text { Lysozyme, } \\
\text { lactoperoxidase, } \\
\text { lactoferrin }\end{array}$ & $\begin{array}{l}\text { Analysis of } \\
\text { bactericides, } \\
\text { proteins }\end{array}$ & $\begin{array}{l}\text { Ekstrand and } \\
\text { Björck (1986) }\end{array}$ \\
\hline \multirow[t]{2}{*}{$\begin{array}{l}\text { Phenil-superose } \\
\mathrm{Hr} 5 / 5\end{array}$} & $\begin{array}{l}\text { a) } 0.8 \mathrm{M} \text {-Sodium } \\
\text { phosphate, } 3.75 \mathrm{M} \text {-urea, } \\
\text { pH } 6.0 \mathrm{~b}) 0.05 \mathrm{M} \text {-sodium } \\
\text { phosphte, } 3.75 \text { M-urea, pH } 6.0\end{array}$ & $\begin{array}{l}280 \mathrm{~nm} \\
.0\end{array}$ & $\begin{array}{l}\text { Hydrophobic } \\
\text { interaction }\end{array}$ & Caseins & $\begin{array}{l}\text { Study of } \\
\text { hydrophobic } \\
\text { interaction }\end{array}$ & Chaplin (1986) \\
\hline & $\begin{array}{l}\text { a) } 1.5 \mathrm{M} \text { - }\left(\mathrm{NH}_{4}\right)_{2} \mathrm{SO}_{4} \text {, } \\
0.05 \mathrm{M} \text {-sodium } \\
\text { phosphate, } \mathrm{pH} 7 \\
\text { b) } 0.05 \mathrm{M} \text {-sodium } \\
\text { phosphate, pH } 7.0\end{array}$ & & & Whey proteins & & \\
\hline Mono Q Hr 5/5 & $\begin{array}{l}\text { a) } \mathrm{H}_{2} \mathrm{O} \text { B) } 0.7 \mathrm{M} \text {-sodium } \\
\text { acetate, } \mathrm{pH} 6.3\end{array}$ & $280 \mathrm{~nm}$ & $\begin{array}{c}\text { Anion } \\
\text { exchange }\end{array}$ & Whey proteins & $\begin{array}{l}\text { Separation of } \\
\text { whey proteins }\end{array}$ & Hill et al (1987) \\
\hline Superose 12 & $\begin{array}{l}0.15 \mathrm{M}-\mathrm{NaCl} \\
0.05 \mathrm{M}-\mathrm{Ph} \text { sphate, } \\
\text { pH } 7.0\end{array}$ & & $\begin{array}{l}\text { Size } \\
\text { exclusion }\end{array}$ & & & \\
\hline PRO-RPC & $\begin{array}{l}\text { a) } 0.1 \% \text { TFA in } \mathrm{H}_{2} \mathrm{O} \\
\text { b) } 0.1 \% \text { TFA in } \\
30 \% \mathrm{CH}_{3} \mathrm{CN}\end{array}$ & $215 \mathrm{~nm}$ & $\begin{array}{l}\text { Reversed } \\
\text { phase }\end{array}$ & $\begin{array}{l}\text { Proteins, } \\
\text { peptides }\end{array}$ & $\begin{array}{l}\text { To determine the } \\
\text { extent of proteolysis }\end{array}$ & $\begin{array}{l}\text { Haasnoot et al } \\
(1987)\end{array}$ \\
\hline $\begin{array}{l}\text { TSK } 3000 \text { SW + } \\
2000 \text { SW }\end{array}$ & $\begin{array}{l}0.1 \mathrm{M}-\mathrm{Na}_{2} \mathrm{SO}_{4}, \\
0.02 \mathrm{M}-\mathrm{NaH}_{2} \mathrm{PO}_{4}, \\
\text { pH } 6.8,6 \mathrm{M} \text {-urea }\end{array}$ & $280 \mathrm{~nm}$ & $\begin{array}{c}\text { Size } \\
\text { exclusion }\end{array}$ & & & \\
\hline
\end{tabular}




\begin{tabular}{|c|c|c|c|c|c|c|}
\hline \multirow[b]{2}{*}{ Stationary phase } & \multirow[b]{2}{*}{ Eluent } & \multicolumn{2}{|c|}{ Chromatographic } & \multirow[b]{2}{*}{ Separation of: } & \multirow[b]{2}{*}{ Objective } & \multirow[b]{2}{*}{ Reference } \\
\hline & & Detection & mode & & & \\
\hline Mono Q Hr 5/5 & $\begin{array}{l}\text { TRIS- } \mathrm{HCl} \mathrm{pH} 8.5 \text {, } \\
6 \mathrm{M}-U \text { rea (0-1 } \\
\mathrm{M}-\mathrm{NaCl} \text { gradient) }\end{array}$ & & $\begin{array}{c}\text { Anion } \\
\text { exchange }\end{array}$ & $\begin{array}{l}\text { Proteins, } \\
\text { peptides }\end{array}$ & $\begin{array}{l}\text { To determine } \\
\text { the extent of } \\
\text { proteolysis }\end{array}$ & $\begin{array}{l}\text { Haasnoot et al } \\
(1987)\end{array}$ \\
\hline Mono S Hr 5/5 & $\begin{array}{l}\text { Citric acid } \mathrm{pH} 3.2, \\
6 \mathrm{M}-\mathrm{Urea} \\
(0-0.5 \mathrm{M}-\mathrm{NaCl} \text { gradient) }\end{array}$ & & $\begin{array}{c}\text { Cation } \\
\text { exchange }\end{array}$ & & & \\
\hline Lichrosorb RP-8 & $\begin{array}{l}\text { a) } 0.1 \% \text { TFA in } \mathrm{H}_{2} \mathrm{O} \text {, } \\
0.001 \mathrm{M} \text {-DTT } \\
\text { b) } 0.1 \% \text { TFA in } \\
\text { propan-2-ol }\end{array}$ & $254 \mathrm{~nm}$ & $\begin{array}{l}\text { Reversed } \\
\text { phase }\end{array}$ & Caseins & $\begin{array}{l}\text { Purification of } \\
\text { caseins } \\
\text { identification of } \\
\alpha_{s 1} \text {-caseina }\end{array}$ & $\begin{array}{l}\text { Mikkelsen et al } \\
\text { (1987) }\end{array}$ \\
\hline Mono Q HR 5/5 & $\begin{array}{l}0.005 \mathrm{M} \text {-BIS-TRIS- } \\
\text { Propane pH } 7,3 \text {, } \\
3 \mathrm{M}-\text { Urea }(0-0.43 \\
\mathrm{M}-\mathrm{NaCl} \text { gradient) }\end{array}$ & $280 \mathrm{~nm}$ & $\begin{array}{c}\text { Anion } \\
\text { exchange }\end{array}$ & Caseins & $\begin{array}{l}\text { Quantitative } \\
\text { fractionation of } \\
\text { casein mixtures }\end{array}$ & $\begin{array}{l}\text { Davies and Law } \\
(1987)\end{array}$ \\
\hline Vyadec 214 TP & $\begin{array}{l}\text { a) } 0.1 \% \text { TFA in } \\
30 \% \mathrm{CH}_{3} \mathrm{CN} \\
\text { b) } 0.1 \% \text { TFA in } \\
45 \% \mathrm{CH}_{3} \mathrm{CN}\end{array}$ & $\begin{array}{l}280 \\
210 \\
230 \\
250 \mathrm{~nm}\end{array}$ & $\begin{array}{l}\text { Reversed } \\
\text { phase }\end{array}$ & Whey proteins & $\begin{array}{l}\text { Determination of } \\
\text { whey proteins } \\
\text { and their } \\
\text { functionality }\end{array}$ & Kim et al (1987) \\
\hline Mono Q Hr 5/5 & $\begin{array}{l}0.005 \mathrm{M}-\mathrm{TRIS}-\mathrm{HCl} \\
\mathrm{pH} 8.0,4.5 \mathrm{M} \text {-Urea } \\
6.4 \times 10^{-5} \mathrm{M}-\mathrm{DTT} \\
(0.12-0.32 \mathrm{M}-\mathrm{NaCl} \\
\text { gradient) }\end{array}$ & $280 \mathrm{~nm}$ & $\begin{array}{c}\text { Anion } \\
\text { exchange }\end{array}$ & Caseins & $\begin{array}{l}\text { Quantitative } \\
\text { analysis caseins }\end{array}$ & $\begin{array}{l}\text { Guillou et al } \\
\text { (1987) }\end{array}$ \\
\hline
\end{tabular}




\begin{tabular}{|c|c|c|c|c|c|c|}
\hline \multirow[b]{2}{*}{ Stationary phase } & \multirow[b]{2}{*}{ Eluent } & \multirow[b]{2}{*}{ Detection } & \multicolumn{2}{|c|}{ Chromatographic } & \multirow[b]{2}{*}{ Objective } & \multirow[b]{2}{*}{ Reference } \\
\hline & & & mode & Separation of: & & \\
\hline TSK-G 2000 SW & $\begin{array}{l}0.1 \mathrm{M}-\mathrm{KH}_{2} \mathrm{PO}_{4} \\
0.01 \mathrm{M}-\mathrm{K}_{2} \mathrm{HPO}_{4} \\
0.15 \mathrm{M}-\mathrm{Na}_{2} \mathrm{SO}_{4}\end{array}$ & $280 \mathrm{~nm}$ & $\begin{array}{c}\text { Size } \\
\text { exclusion }\end{array}$ & Whey proteins & $\begin{array}{l}\text { To recover } \\
\text { whey proteins }\end{array}$ & $\begin{array}{l}\text { Murphy and } \\
\text { Mulvihill (1988) }\end{array}$ \\
\hline Zorbax GF-250 & $\begin{array}{l}0.1 \mathrm{M}-\mathrm{KH}_{2} \mathrm{PO}_{4} \\
0.01 \mathrm{M}-\mathrm{K}_{2} \mathrm{HPO}_{4} \\
0.15 \mathrm{M}-\mathrm{Na}_{2} \mathrm{SO}_{4}\end{array}$ & $280 \mathrm{~nm}$ & $\begin{array}{c}\text { Size } \\
\text { exclusion }\end{array}$ & Whey proteins & $\begin{array}{l}\text { Evaluation of } \\
\text { heat treatment }\end{array}$ & $\begin{array}{l}\text { Van Den Bedem and } \\
\text { Leenheer (1988) }\end{array}$ \\
\hline $\begin{array}{l}\text { Phenil-superose } \\
\mathrm{Hr} 5 / 5\end{array}$ & $\begin{array}{l}\text { a) } 0.05 \mathrm{M}-\mathrm{TRIS}-\mathrm{HCl} \\
\mathrm{pH} 7.5,1.27 \\
\mathrm{M}-\left(\mathrm{NH}_{4}\right)_{2} \mathrm{SO}_{4} \\
\text { b) } 0.05 \mathrm{M}-\mathrm{TR} \mathrm{S}-\mathrm{HCl} \\
\text { pH } 7.5 \text { in } 35 \% \mathrm{CH}_{3} \mathrm{CN}\end{array}$ & $280 \mathrm{~nm}$ & $\begin{array}{l}\text { Hydrophobic } \\
\text { interaction }\end{array}$ & Whey proteins & $\begin{array}{l}\text { Evaluation of } \\
\text { heat treatment }\end{array}$ & $\begin{array}{l}\text { Dumay and } \\
\text { Cheftel (1989) }\end{array}$ \\
\hline Mono Q Hr 5/5 & $\begin{array}{l}0.02 \mathrm{M}-\text { Piperazine, } \\
\text { pH } 6.0 \text { (0.02-1 M-NaCl } \\
\text { gradient) }\end{array}$ & & $\begin{array}{c}\text { Anion } \\
\text { exchange }\end{array}$ & & & \\
\hline Superose 12 & $\begin{array}{l}0.6 \mathrm{M}-\text { Potasium } \\
\text { phosphate } \mathrm{pH} 6.0 \text {, } \\
0.15 \mathrm{M}-\mathrm{Na}_{2} \mathrm{SO}_{4}\end{array}$ & & $\begin{array}{c}\text { Size } \\
\text { exclusion }\end{array}$ & & & \\
\hline
\end{tabular}


In acid conditions, it is necessary to dilute the sample with urea to avoid precipitation of caseins on the column. It is interesting to observe that with reversed phase (Visser et al, 1986) these authors obtain a better separation between $\alpha_{\mathrm{s} 2}$ and $\alpha_{\mathrm{s} 1}$-casein than with a Mono $Q$ column. This is also true with hydrophobic interaction column (Chaplin, 1986). So the latter could be used as a second step for rapid purification of $\alpha_{\text {s2 }}$-casein after a first step on an ion exchange column. Genetic variants can also be separated using longer analysis times (approximately $1 \mathrm{~h}$ ) than those used for Mono $\mathrm{Q}$ columns. The advantage of this technique, compared to the other methods discussed above, is that volatile buffers are used, which enables recovery of proteins merely by freeze-drying the eluate.

\section{Applications}

One practical application of the HPLC analysis of caseins is to detect admixtures of milks of different species. Haasnoot et al (1986b) described a technique for detecting cow's milk in ewe's milk, goat's milk, and Gouda-type cheese made from these milks using ion-exchange chromatography on Mono- $Q$ column. Bovine $\alpha_{s}$ casein was used as an indicator to detect the presence of cow's milk in ewe's and goat's milk, curd, and non-proteolyzed cheese, with a detection limit of $2-4 \%$ and $\alpha_{s 1}$-l-peptide was used for old cheese, with a detection limit of $10 \%$. These results are comparable to those obtained using electrophoretic and immunological methods.

HPLC analysis of caseins can also be used to determine the degree of ripening of cheese, a topic of great interest in the dairy sector. Chemical, physical, and sensory indices have been applied; among these, the chemical parameters, and in particular those related to proteolysis, appear to be most promising. The nitrogen index actually used furnished no information on individual components, and evaluation procedures are slow. HPLC separation and quantification of constituent compounds in caseins may provide a better indication of ripening time.

Haasnoot et al (1987) prepared cheese extracts at various stages of ripening in water, trichloroacetic acid, and urea and performed separations using reversedphase, ion-exchange, and gel permeation chromatography. Separation by means of anionic exchange of urea extracts seemed to be the most appropriate method for determining the extent of proteolysis. According to the authors, the peak areas of $\gamma$ and $\beta$-caseins are useful as a ripening index for old cheeses, those of $\alpha_{\mathrm{s} 1}$ and $\alpha_{\mathrm{s2}}$-caseins for young cheeses.

\section{Whey proteins}

The first HPLC separations of whey proteins were performed on gel permeation columns (Diosady et al, 1980; Dimenna and Segall, 1981), but the resolution of the major proteins $(\beta-\mathrm{lg}, \alpha$-la, and BSA) was incomplete, even though 2 columns were used in series. Today, the development of more efficient columns (Toya Soda 2000 SW and 3000 SW columns), combined with the use of phosphate buffer with sulphate or $\mathrm{NaCl}$ at a pH of 6.8 , have made it possible to separate the $\mathrm{lg}$ G, BSA, $\beta \mathrm{lg}$, and the dimeric and monomeric forms of $\alpha$-la in about 30 min (Gupta, 1983; Murphy and Mulvihill, 1988). When elution takes place in the presence of SDS (Gupta, $1983)$, there is only 1 peak of $\alpha$-la.

Diosady et al (1980) described a nearly complete separation by reversed-phase 
chromatography on a $\mathrm{C}_{\mathrm{s}}$ column. Pearce (1983) achieved effective separation of the major whey proteins using a reversedphase $\mathrm{C}_{6}$ column and even succeeded in separating genetic variants of $\beta$-lg. De Frutos et al (1987) using a C-4 reversed phase column separated BSA, $\alpha$-la and $\beta$ Ig $B$ and $A$ in about 6 min.

lon-exchange chromatography has also been used to analyze whey proteins. The best resolution and shortest analysis times have been obtained using anionic Mono $Q$ FPLC columns with a pH 6-7 buffer and a $\mathrm{NaCl}$ gradient, but buffers used for the separation of whey proteins do not contain urea conversely to casein separation (Humphrey and Newsome, 1984; Andrews et al, 1985). Utilization of the phenylsuperose HR $5 / 5$ bonded phase has made the separation of proteins possible on the basis of hydrophobicity. Effective hydrophobicity can be measured, despite its poor correlation with hydrophobicity as calculated from the Bigelow number. According to Chaplin (1986), the former is probably more closely related to the functional properties of the proteins than the latter.

De Frutos et al (1988) using hydrophobic interaction chromatography on a column of polyether phase bonded to silica support separated BSA, $\alpha$-la and $\beta$-lg. With this technique it is not possible to separate genetic variants of $\beta$-lg, nevertheless it enables the recovery of proteins in their native state.

Dumay and Cheftel (1989) studied the behaviour of a concentrate of $\beta-\mathrm{lg}$ using different separation mechanisms: hydrophobic interaction, anion exchange and gel permeation. The results shown in figure 2 are similar to those previously described. lon exchange chromatography gives the best separation of $\beta$-lg genetic variants $A$ and B. Nevertheless, gel permeation chromatography might be useful for detecting soluble aggregates. Quantitative meas- urement of $\beta$-lg or $\alpha$-la by hydrophobic interaction chromatography are quite precise, giving variation coefficients equal to or lower than $4-5 \%$. On a Sepharose 12 column, variation coefficients are lower for $\beta$-lg and somewhat higher for $\alpha-\mathrm{la}$. Reten-
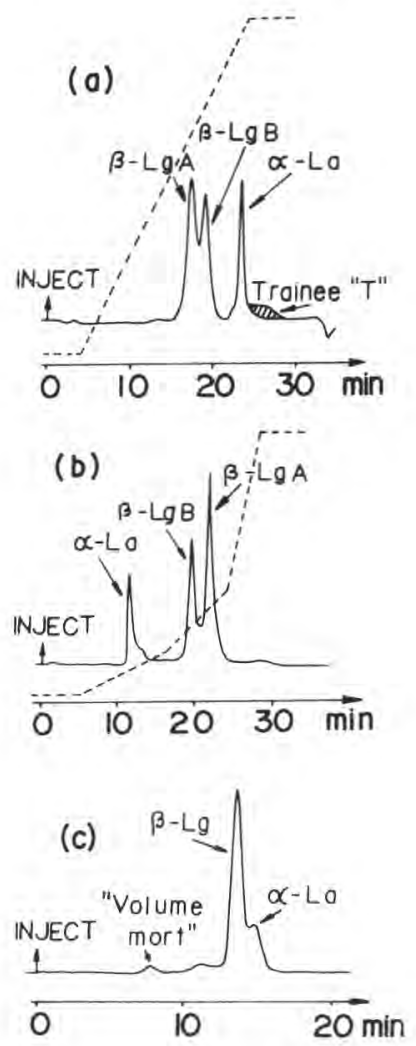

Fig 2. Chromatographic patterns of soluble proteins from $\beta$-lactoglobulin concentrate: a) hydrophobic interaction (Phenyl Superose column); b) anion exchange (Mono $Q$ column); c) gel permeation (Superose 12 column). For elution conditions: see table I. [From Dumay and Cheftel (1989), Sci Aliments 9, 561, with permission]. Profils de la fraction soluble du concentré de $\beta$ lactoglobuline obtenus par chromatographie a) d'interaction hydrophobe (colonne Phenyl Superose); b) d'échange d'anions (colonne Mono Q); c) de perméation de gel (colonne Superose 12). Conditions d'élution: voir tableau I. 
tion times for protein constituents remain relatively constant and with variation coefficients lower than $2 \%$ for $3-6$ injections of the same protein solution.

\section{Applications}

Evaluation of the heat processing undergone by powdered skim milk is one of the practical applications of the HPLC separation of whey proteins. Kneifel and Ulberth (1985) suggested a gel permeation-based HPLC method to quantify the whey proteins without denaturing reconstituted powdered milk samples. This method was more sensitive than the American Dry Milk Institute, method (1971). Subsequently, Manji and Kakuda (1986) analyzed skim milks subjected to several different timetemperature treatment combinations, using FPLC to monitor the amount of thermal denaturation. The denaturation reaction appeared to follow a first-order kinetic equation in the case of $\alpha$-la and secondorder kinetic equations for $\beta-\lg A$ and $B$; at temperatures above $90^{\circ} \mathrm{C}$, denaturation of $\beta-\lg B$ took place slightly faster than that of $\beta$-lg A. Van den Bedem and Leenheer (1988) later described a high performance gel permeation chromatographic method suitable for classifying the type of heat processing used to produce powdered milk when low or extra-low heat treatments were employed.

Another application of whey protein separation by high performance gel filtration chromatography is to detect colostrum in milk. In comparison to whey, colostrum has a high immunoglobulin content, particularly lg G Haasnoot et al (1986b) employed high performance gel filtration to detect the adulteration of milk with colostrum, and they established that Ig G levels in milk above $0.75 \mathrm{mg} / \mathrm{ml}$ were indicative of adulteration with colostrum.

\section{PEPTIDE ANALYSIS}

Different peptides exhibit a wide range of molecular weights and consequently distinct methodologies are used in the separation of these compounds. Reversedphase chromatography on conventional columns with a small pore size is used for the smallest peptides (molecular weight lower than $3000 \mathrm{Da}$ ). For larger peptides, reversed-phase columns with large pore sizes or gel permeation are suitable.

Table II summarizes the main papers dealing with peptide analysis in dairy products published in recent years. Most of the work has employed absorbance detectors operating between 205 and $230 \mathrm{~nm}$, though $280 \mathrm{~nm}$ has also been utilized for the larger peptides. Reversed-phase chromatography has proved to be a reliable method with high resolving power for separating peptides from casein hydrolysates. Lemieux and Amiot (1989) fractionated peptides from phosphorylated and dephosphorylated casein hydrolysates on a TSK G 2000 SW column and separated the fractionated peptides by RP-HPLC on a $\mathrm{C}_{18}$ column. The separation of phosphorylated and dephosphorylated hydrolysates yielded, respectively, 187 and 213 peptides, of which 99 and 116 were identified. Their study revealed that the peptide separation mechanism includes ionic interactions, hydrogen bonding, and peptide properties, in addition to overall peptide hydrophobicity.

\section{Applications}

Proteolysis of caseins, in particular proteolysis of the most hydrophobic caseins, ie, the $\beta$-caseins, is known to produce bitter peptides. There seems to be a relationship between hydrophobicity and bitterness, and therefore, RP-HPLC could be a useful 
method for separating bitter from non-bitter peptides. Champion and Stanley (1982) used RP-HPLC on a $\mathrm{C}_{18}$ column to separate extracts of bitter peptides from Cheddar cheese coagulated with pepsin. A total of 71 substances, some of them bitter, were found, and the bitter fraction was reported to exhibit slightly higher mean hydrophobicity values and to present higher valine and leucine contents than the non-bitter fraction.

Leadbeater and Bruce-Ward (1987) using RP-HPLC after hydrolysis of $\beta$-casein with trypsin, separated the fragments into 16 peptides; identified them by means of external standards and $\mathrm{N}$-terminal analysis using dansylation followed by partial Edman degradation. Retention of phosphoserine-containing peptides and large $(>1500$ Da) peptides was longer than expected from their mean hydrophobicity values and the authors therefore suggested that other factors, such as column pore size and peptide size, might also exert an influence on the separation results. However, there was a reasonable correlation between hydrophobicity and retention times for most individual peptides. Similar results were described by Carles and Ribadeau-Dumas (1986).

These methods, initially developed for the study of milk protein ( $\beta$-casein) proteolysis, are currently applied to examine the action of the extracellular proteases of lactic acid bacteria on milk proteins. Monnet et al (1986) used RP-HPLC to determine the specificity of a proteinase from the cell wall of Streptococcus lactis on $\beta$-casein.

HPLC analysis of the water-soluble fraction can be useful in obtaining objective evaluation of cheese ripening. Using RPHPLC, Pham and Nakai (1984) separated the water-soluble fraction in Cheddar cheeses at varying stages of ripening (fresh, young, ripe, and old) into 13 peaks, of which 6 increased, 2 decreased, and 4 remained unchanged with age. An additional peak appeared in the old cheese. The proportion of nitrogen compounds in the water-soluble fraction increased from 22 to $35 \%$ after 6 months of ripening (Park et al, 1980).

Gonzalez de Llano et al (1987a) analyzed the phosphotungstic acid soluble peptides from blue cheeses by gel filtration and HPLC.

Kaminogawa et al (1986) purified and identified the main low-molecular-weight peptides in Gouda cheese, confirmed by the formation of the same peptides by the protease fraction from Streptococcus cremoris on $23 \mathrm{~N}$-terminal residues of $\alpha_{51^{-}}$ casein. The chromatograms for the cheese extracts varied according to ripening time, with peak height increasing with age.

Shimizu et al (1986) studied the functional properties (emulsifying capacity) of a 23-residue peptide hydrolyzed from $\alpha$ casein by pepsin and purified by ion exchange chromatography.

Detection of cow's milk in ewe's or goat's milk and cheese is another application of the HPLC analysis of peptides. Tobler et al (1983) used HPLC to examine the difference between the caseins in the milks of various species. Goat's and cow's milk cheese caseins were hydrolyzed with trypsin, and the peptides thus obtained were separated by reversed-phase HPLC. The chromatograms were reproducible and distinct for the caseins of each species. Subsequently, Kaiser and Krause (1985) used HPLC to separate the tryptic peptides in cow's milk and goat's milk cheeses and cheeses made from mixtures of these milks. They reported that the quantitative detection limit could be as low as $1 \%$ cow's milk in goat's-milk cheese. The presence of cow's milk reduced the area of the 80-min peak characteristic of goat's milk. 
Table II. HPLC application to the analysis of peptides in dairy products.

Application de la CLHP au dosage des peptides dans les produits laitiers.

\begin{tabular}{|c|c|c|c|c|c|c|}
\hline \multirow[b]{2}{*}{ Stationary phase } & \multirow[b]{2}{*}{ Eluent } & \multicolumn{3}{|c|}{ Chromatographic } & \multirow[b]{2}{*}{ Objective } & \multirow[b]{2}{*}{ Reference } \\
\hline & & Detection & mode & Separation of: & & \\
\hline TSK 2000 SW & $\begin{array}{l}0.1 \mathrm{M}-\mathrm{KH}_{2} \mathrm{PO}_{4} \\
0.01 \mathrm{M}_{2} \mathrm{~K}_{2} \mathrm{HPO}_{4,}, \\
0.15 \mathrm{M}-\mathrm{Na}_{2} \mathrm{SO}_{4}\end{array}$ & $205 \mathrm{~nm}$ & $\begin{array}{c}\text { Size } \\
\text { exclusion }\end{array}$ & Glycomacropeptide & $\begin{array}{l}\text { Action of chymosin } \\
\text { in milk }\end{array}$ & $\begin{array}{l}\text { Van Hooydonk and } \\
\text { Olieman (1982) }\end{array}$ \\
\hline$\mu$-Bondapak C18 & $\begin{array}{l}\text { a) } \mathrm{H}_{2} \mathrm{O} \\
\text { b) methanol }\end{array}$ & $280 \mathrm{~nm}$ & $\begin{array}{l}\text { Reversed } \\
\text { phase }\end{array}$ & Peptides & $\begin{array}{l}\text { Separation of } \\
\text { bitter peptides }\end{array}$ & $\begin{array}{l}\text { Champion and } \\
\text { Stanley (1982) }\end{array}$ \\
\hline TSK 2000 SW & $\begin{array}{l}0.1 \mathrm{M}-\mathrm{KH}_{2} \mathrm{PO}_{4,} \\
0.01 \mathrm{M}-\mathrm{K}_{2} \mathrm{HPO}_{4,}, \\
0,15 \mathrm{M}-\mathrm{Na}_{2} \mathrm{SO}_{4}\end{array}$ & $205 \mathrm{~nm}$ & $\begin{array}{c}\text { Size } \\
\text { exclusion }\end{array}$ & Glycomacropeptide & $\begin{array}{l}\text { To detect rennet } \\
\text { whey in milk } \\
\text { powder }\end{array}$ & $\begin{array}{c}\text { Olieman and } \\
\text { Van den Bedem } \\
(1983)\end{array}$ \\
\hline $\begin{array}{l}\text { Spherisorb S5 C8 } \\
\text { Adsorbosphere C8 } \\
\text { Vydak C18 }\end{array}$ & $\begin{array}{l}\text { 0.1 M-Buffer phosphate } \\
\text { pH } 6.0\end{array}$ & $220 \mathrm{~nm}$ & $\begin{array}{l}\text { Reversed } \\
\text { phase }\end{array}$ & Peptides & $\begin{array}{l}\text { To determine the } \\
\text { maturity of cheese }\end{array}$ & $\begin{array}{l}\text { Pham and Nakai } \\
(1984)\end{array}$ \\
\hline $\begin{array}{l}\text { Lichrospher } \\
\text { Si-500/2 CH8 }\end{array}$ & $\begin{array}{l}\text { a) } 0.005 \mathrm{M} \text {-Ammonium } \\
\text { acetate } \mathrm{pH} 7.25 \\
\text { b) Idem a) }+65 \% \text { ethanol }\end{array}$ & $220 \mathrm{~nm}$ & $\begin{array}{l}\text { Reversed } \\
\text { phase }\end{array}$ & Peptides & $\begin{array}{l}\text { To detect mixtures } \\
\text { of milk }\end{array}$ & $\begin{array}{c}\text { Kaiser and Krause } \\
\text { (1985) }\end{array}$ \\
\hline TSK 2000 SW & 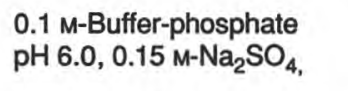 & $205 \mathrm{~nm}$ & $\begin{array}{c}\text { Size } \\
\text { exclusion }\end{array}$ & Glycomacropeptide & $\begin{array}{l}\text { Proteolysis in } \\
\text { raw milk }\end{array}$ & Mottar et al (1985) \\
\hline$\mu$-Bondapak C18 & $\begin{array}{l}\text { a) } 0.01 \text { M-potasium- } \\
\text { phosphate, pH } 6.5 \\
\text { b) Idem a) }+60 \% \mathrm{CH}_{3} \mathrm{CN}\end{array}$ & $220 \mathrm{~nm}$ & $\begin{array}{l}\text { Reversed } \\
\text { phase }\end{array}$ & Peptides & $\begin{array}{l}\text { Separation of } \\
\text { peptide mixture }\end{array}$ & $\begin{array}{l}\text { Carles and } \\
\text { Ribadeau-Dumas } \\
\qquad(1986)\end{array}$ \\
\hline RP-300 A & $\begin{array}{l}\text { a) } 0.02 \% \mathrm{SDS} \text {, } \\
0.02 \% \mathrm{TFA}, \mathrm{pH} 5.5 \\
\text { b) Idem a) }+50 \% \mathrm{CH}_{3} \mathrm{CN}\end{array}$ & $210 \mathrm{~nm}$ & $\begin{array}{l}\text { Reversed } \\
\text { phase }\end{array}$ & Peptides & $\begin{array}{l}\text { To detect mixtures } \\
\text { of milks }\end{array}$ & $\begin{array}{c}\text { Windemann et al } \\
\text { (1986) }\end{array}$ \\
\hline Zorbax-ODS & $\begin{array}{l}\text { a) } 0.1 \% \text { TFA in } \mathrm{H}_{2} \mathrm{O} \\
\text { b) } 0.1 \text { TFA in } 60 \% \mathrm{CH}_{3} \mathrm{CN}\end{array}$ & $230 \mathrm{~nm}$ & $\begin{array}{l}\text { Reversed } \\
\text { phase }\end{array}$ & Peptides & $\begin{array}{l}\text { Identification of } \\
\text { low molecular } \\
\text { weight peptides }\end{array}$ & $\begin{array}{c}\text { Kaminogawa et al } \\
(1986)\end{array}$ \\
\hline
\end{tabular}




\begin{tabular}{|c|c|c|c|c|c|c|}
\hline \multirow[b]{2}{*}{ Stationary phase } & \multirow[b]{2}{*}{ Eluent } & \multicolumn{3}{|c|}{ Chromatographic } & \multirow[b]{2}{*}{ Objective } & \multirow[b]{2}{*}{ Reference } \\
\hline & & Detection & mode & Separation of: & & \\
\hline Finepak-SIL ODS & $\begin{array}{l}\text { a) } 0.1 \% \text { TFA in } \mathrm{H}_{2} \mathrm{O} \\
\text { b) } 0.1 \% \text { TFA in } \\
40 \% \mathrm{CH}_{3} \mathrm{CN}\end{array}$ & $230 \mathrm{~nm}$ & $\begin{array}{l}\text { Reversed } \\
\text { phase }\end{array}$ & Peptides & $\begin{array}{l}\text { Properties of a } \\
\text { peptide } \\
\alpha_{\mathrm{s} 1} \mathrm{CN}-(\mathrm{fl23})\end{array}$ & Shimizu et al (1986) \\
\hline Ultrasphere ODS & $\begin{array}{l}\text { a) } 0.1 \% \text { TFA in } \mathrm{H}_{2} \mathrm{O} \\
\text { b) } 0.1 \% \text { TFA in } \\
30 \% \mathrm{CH}_{3} \mathrm{CN}\end{array}$ & $230 \mathrm{~nm}$ & $\begin{array}{l}\text { Reversed } \\
\text { phase }\end{array}$ & Peptides & $\begin{array}{l}\text { Study of low } \\
\text { molecular weight } \\
\text { peptides }\end{array}$ & $\begin{array}{c}\text { Gonzalez-Llano et al } \\
\text { (1987a) }\end{array}$ \\
\hline Apex C8 & $\begin{array}{l}\text { a) } 0.1 \% \text { TFA in } \mathrm{H}_{2} \mathrm{O} \\
\text { b) } 0.08 \% \text { TFA in } \\
50 \% \mathrm{CH}_{3} \mathrm{CN}\end{array}$ & $206 \mathrm{~nm}$ & $\begin{array}{l}\text { Reversed } \\
\text { phase }\end{array}$ & Peptides & $\begin{array}{l}\text { Study of } \\
\text { proteolysis }\end{array}$ & $\begin{array}{l}\text { Leadbeater and } \\
\text { Bruce-Ward (1987) }\end{array}$ \\
\hline TSK 2000 SW & $\begin{array}{l}0.1 \mathrm{M}^{-\mathrm{KH}_{2}} \mathrm{PO}_{4,}, \\
0.01 \mathrm{M}-\mathrm{K}_{2} \mathrm{HPO}_{4,} \\
0.15 \mathrm{M}-\mathrm{Na}_{2} \mathrm{SO}_{1}\end{array}$ & $205 \mathrm{~nm}$ & $\begin{array}{c}\text { Size } \\
\text { exclusion }\end{array}$ & Glycomacropeptide & $\begin{array}{l}\text { Fractionationation } \\
\text { and characterization } \\
\text { of GMP }\end{array}$ & Morr and Seo (1988) \\
\hline Beckman-RPSD & $\begin{array}{l}\text { a) } 0.15 \mathrm{M}-\mathrm{NaCl}-\mathrm{HCl} \text {, } \\
\mathrm{pH} 2.1 \mathrm{~b}) \mathrm{CH}_{3} \mathrm{CN} \\
\text { a) } 0.01 \mathrm{M}-\mathrm{TFA} \text { in } \\
\mathrm{H}_{2} \mathrm{O} \text { b) } 0.01 \mathrm{M}-\mathrm{TFA} \text { in } \\
\mathrm{CH}_{3} \mathrm{CN}\end{array}$ & $210 \mathrm{~nm}$ & $\begin{array}{l}\text { Reversed } \\
\text { phase }\end{array}$ & & & \\
\hline TSK G 2000 SW & $\begin{array}{l}0.1 \% \text { TFA, } 0.05 \\
\text { M-Buffer phosphate, } \\
35 \% \text { methanol }\end{array}$ & $214 \mathrm{~nm}$ & $\begin{array}{c}\text { Size } \\
\text { exclusion }\end{array}$ & Peptides & $\begin{array}{l}\text { Separation of } \\
\text { peptides }\end{array}$ & $\begin{array}{l}\text { Lemieux and Amiot } \\
\text { (1989) }\end{array}$ \\
\hline$\mu$-Bondapak C18 & $\begin{array}{l}\text { a) } 0.115 \% \text { TFA in } \mathrm{H}_{2} \mathrm{O} \\
\text { b) } 0.1 \% \text { TFA in } \\
60 \% \mathrm{CH}_{3} \mathrm{CN}\end{array}$ & $206 \mathrm{~nm}$ & $\begin{array}{l}\text { Reversed } \\
\text { phase }\end{array}$ & & & \\
\hline Ultrapore RPSC & $\begin{array}{l}\text { a) } 0.1 \% \text { TFA in } 15 \% \\
\mathrm{CH}_{3} \mathrm{CN} \text { b) } 0.1 \% \text { TFA } \\
\text { in } 30 \% \mathrm{CH}_{3} \mathrm{CN}\end{array}$ & $210 \mathrm{~nm}$ & $\begin{array}{l}\text { Reversed } \\
\text { phase }\end{array}$ & Glycomacropeptide & $\begin{array}{l}\text { To detect rennet } \\
\text { whey solids in } \\
\text { milk and butter } \\
\text { milk powders }\end{array}$ & $\begin{array}{l}\text { Olieman and } \\
\text { Van Riel (1989) }\end{array}$ \\
\hline Protein Plus & $\begin{array}{l}\text { a) } 0.1 \% \text { TFA in } 15 \% \\
\mathrm{CH}_{3} \mathrm{CN} \text { : } 2 \% \text { isopropanol } \\
\text { b) } 0.1 \% \text { TFA in } 55 \% \\
\mathrm{CH}_{3} \mathrm{CN}: 2 \% \text { isopropanol }\end{array}$ & $210 \mathrm{~nm}$ & $\begin{array}{l}\text { Reversed } \\
\text { phase }\end{array}$ & & & \\
\hline
\end{tabular}


The cleavage of the bond Phe 105-Met 106 of K-casein, which is responsible for the milk coagulation, liberates the glycomacropeptide (GMP) (fragment 106-169 of K-casein). This high-molecular-weight peptide can be recovered by ultrafiltration of cheese whey. The price of cheese whey being very low, it is used to adulterate powdered milk, and hence detection of this peptide could be used as an adulteration index.

Van Hooydonk and Olieman (1982) studied the action of chymosin in milk and quantified GMP by means of gel filtration HPLC. The method enabled them to determine the proteolytic activity of commercial rennets and rennet substitutes. Olieman and Van Den Bedem (1983) established the amount of whey in powdered skim milks by measuring the amount of GMP. The procedure was more sensitive than other tests available (determination of lactic acid, ash, sialic acid, etc) and offered the advantage of being unaffected by the procedure used to produce the whey. However, the interpretation of gel permeation chromatograms of acid buttermilk is sometimes complicated by the presence of components eluting closely after the glycomacropeptide (De Vilder et al, 1988). On the other hand, during prolonged cold storage of milk or butter-milk, psychrotrophic bacteria might proliferate and induce enzymatic proteolysis of caseins. This leads to false positive results. Recently Olieman and Van Riel (1989) developed a procedure which is more selective than the existing GPC method. It is based on the determination of GMP with HPLC on a reversed phase Protein Plus Column with a gradient of acetonitrile water containing $0.1 \%$ of trifluoroacetic acid. The sequential application of the 2 methods diminishes the chance of false positive results. The authors found no evidence that starters used for ripening cream produce enzymes which split K-casein at the same bond as chymosin. Some starters formed pseudoGMP. Under practical circumstances it is also highly unlikely that psychrotrophic bacteria produce enzymes capable of splitting $\mathrm{K}$-casein at the same bond as chymosin.

HPLC quantification of the degradation products of raw-milk proteins may furnish information on the shelf life of subsequently prepared UHT milk. Based on 2 earlier methods, Mottar et al (1985) applied HPLC to determine the specific proteolytic components which provide information concerning the presence and activity of Gramnegative psychrotrophic bacteria.

This information is important for monitoring milk products, especially UHT milk, since they produce heat-resistant proteolytic enzymes that can limit storage life. The method can be used to determine whether raw milk is suitable for the manufacture of UHT milk.

Morr and Seo (1988) carried out a more thorough evaluation of GMP (effective molecular weight and physico-chemical properties) and of methods for fractionating and quantifying this substance in dairy products.

\section{ANALYSIS OF AMINO ACIDS AND AMINES}

Although HPLC has been used for some time in the study of amino acids, the literature contains very few applications of this technique to dairy products.

Since the absorption maximum for amino acids falls in the same region of the spectrum (214 nm) as those of many other compounds, fluorescent derivates are often formed for detection purposes. The most frequently used derivatizing agents are dansyl chloride and orthophtaldehyde/ 
mercaptoethanol, and both reagents have been applied to the study of dairy products (Polo et al, 1985; Ramos et al, 1987; González de Llano et al, 1987b). Table III summarizes the most recent work on HPLC analysis of amino acids and amines in milk products. All separations have been performed using reversed-phase chromatography.

Polo et al (1985) studied free amino acids in artisanal and industrial Mahon cheese during ripening. For this purpose, amino acid derivatives were formed with dansyl chloride and separated on a Radial Pak $\mathrm{C}_{18}$ column in little more than $50 \mathrm{~min}$.

Using the fluorescent derivative formed by the reaction of amino acids with orthophthaldehyde (OPA) in the presence of mercaptoethanol, Ramos et al (1987) studied the effect of freezing Cabrales cheese curds on final cheese composition. The free amino acid content in the cheeses produced from curds frozen for 4 months was lower than that in the control cheeses; in contrast, the amino acid content in the cheeses obtained from curds frozen for 8 months was similar to that in the control cheeses.

The reaction of amino acids with orthophthaldehyde/mercaptoethanol can be automated using an automatic injector and a mixing column. This technique has been employed to study the amino acid composition of the phosphotungstic acidsoluble peptides in blue cheese (González-Llano et al, 1987b) and the influence of enzyme-accelerated ripening of Spanish hard cheese on the free amino acid content (Fernández-Garcia et al, 1988). Fig 3 shows the chromatogram obtained in a Gamonedo cheese (González de Llano, 1989).

The fact that OPAMCE does not react with secondary amino acids such as proline and hydroxy-proline and that dansyl chloride appears in the chromatogram as a big peak interferring with the detection of other amino acids, makes it necessary to look for other derivatizing reagents.

The derivatization with phenylisothiocyanate and 9-fluorenyl-metoxycarbonyl which are already used to detect amino acids in other food products, could also give good results in dairy products.

Cheese, like other fermented products, may contain biogenic amines produced by micro-organism-induced decarboxylation of certain amino acids. The detection and quantification of such amines were studied because of their toxic effects on some consumers and HPLC was applied in the determination of these nitrogen compounds in cheese.

Absorbance at $215-220 \mathrm{~nm}$ has been used for the detection of amines and their amino acid precursors in some experiments; however, derivative formation, as in the case of the amino acids mentioned above, is more common, because it facilitates more selective detection.

Antila et al (1984) published an excellent review of the literature dealing with amines in cheeses. In the same paper the authors also presented HPLC determinations of the histamine, tyramine, tryptamine, phenylethylamine, cadaverine, the putrescine contents in a total of 76 Finnish cheeses; these authors reported no relationship between cheese quality and amine content.

Chang et al (1985) used ion-pair chromatography with detection at $220 \mathrm{~nm}$ to determine the tyrosine, tyramine, histidine, histamine, tryptophan, and tryptamine content in cheese samples. Ion-pair chromatography with an ultraviolet detector was also employed by Van Boekel and Arentsen-Stasse (1987) to analyze the same compounds, along with phenylalanine and phenylethylamine, in cheeses. 
Table III. HPLC application to the analysis of amino acids and amines in dairy products.

Application de la CLHP au dosage des acides aminés et amines dans les produits laitiers.

\begin{tabular}{|c|c|c|c|c|c|c|}
\hline Stationary phase & Eluent & Detection & $\begin{array}{l}\text { Chromatographi } \\
\text { mode }\end{array}$ & Separation of: & Derivatization & Reference \\
\hline$\mu$-Bondapak C18 & $\begin{array}{l}\text { a) } 0.02 \mathrm{~N} \text {-acetic, } \mathrm{CH}_{3} \mathrm{CN} \\
\text { b) } 0.02 \mathrm{~N} \text {-acetic, } \mathrm{CH}_{3} \mathrm{CN} \text {, } \\
\text { methanol }\end{array}$ & Fluorescence & $\begin{array}{l}\text { Reversed } \\
\text { phase }\end{array}$ & Amines & Dansyl chloride & $\begin{array}{l}\text { Antila et al } \\
(1984)\end{array}$ \\
\hline$\mu$-Bondapak C18 & $\begin{array}{l}0,02 \mathrm{M} \text {-butane- or, } \\
\text { pentane- or, hexane- or, } \\
\text { heptane- or, octane- or } \\
\text { D-camphoric sulfonic } \\
\text { acid sodium salt in } 15 \% \\
\text { methanol: } 85 \% \mathrm{H}_{2} \mathrm{O} \text {; } \\
10 \% \mathrm{CH}_{3} \mathrm{CN} \text { : } 90 \% \mathrm{H}_{2} \mathrm{O} \text {; } \\
20 \% \mathrm{CH}_{3} \mathrm{CN} \text { : } \\
80 \% \mathrm{H}_{2} \mathrm{O} \text {, pH } 3.0\end{array}$ & $220 \mathrm{~nm}$ & $\begin{array}{c}\text { Reversed } \\
\text { phase }\end{array}$ & $\begin{array}{l}\text { Aromatic amino } \\
\text { acids and their } \\
\text { amines }\end{array}$ & & $\begin{array}{l}\text { Chang et al } \\
\text { (1985) }\end{array}$ \\
\hline Radial Pak C18 & $\begin{array}{l}\text { a) methanol, } \\
0.01 \mathrm{M}-\mathrm{Buffer} \\
\text { phosphate } \mathrm{pH} 6.3 \text {, } \\
(15: 85) \\
\text { b) Idem a) (35:65) }\end{array}$ & Fluorescence & $\begin{array}{l}\text { Reversed } \\
\text { phase }\end{array}$ & Amino acids & Dansyl chloride & $\begin{array}{l}\text { Polo et al } \\
\text { (1985) }\end{array}$ \\
\hline Novapak C18 & $\begin{array}{l}\text { Methanol: } \\
0.05 \mathrm{M}-\mathrm{Na} \text {-phosphate } \\
\text { (85:15), 1.5\% PIC }\end{array}$ & Fluorescence & $\begin{array}{l}\text { Reversed } \\
\text { phase }\end{array}$ & Tyramine & o-Phthaldehyde & $\begin{array}{l}\text { Reuvers et a } \\
\text { (1986) }\end{array}$ \\
\hline Nucleosil C18 & $\begin{array}{l}\text { a) } 16 \mathrm{~g} \text { ninhydrin, } 1.2 \mathrm{~g} \\
\text { hydridantin, } 2 \mathrm{~g} \mathrm{SDS} \text {, } \\
940 \mathrm{ml} \mathrm{DMSO}, 350 \mathrm{ml} \\
2.8 \mathrm{M} \text {-sodium acetate } \\
\text { (pH 5.0) } 710 \mathrm{ml} \mathrm{H}_{2} \mathrm{O}\end{array}$ & $546 \mathrm{~nm}$ & $\begin{array}{l}\text { Reversed } \\
\text { phase }\end{array}$ & Amines & Ninhydrin & $\begin{array}{l}\text { Joosten } \\
\text { and Olieman } \\
\text { (1986) }\end{array}$ \\
\hline Radial Pak C18 & $\begin{array}{l}\text { a) methanol: } 0.01 \\
\text { M-Buffer phosphate, } \\
\text { pH 7.3: THF (19:80:1) } \\
\text { b) methanol: } 0.01 \mathrm{M}-\mathrm{Buffer} \\
\text { phosphate, pH } 7.3(80: 20)\end{array}$ & Fluorescence & $\begin{array}{l}\text { Reversed } \\
\text { phase }\end{array}$ & $\begin{array}{l}\text { Amino acids } \\
\text { and amines }\end{array}$ & o-Phthaldehyde & $\begin{array}{l}\text { Ramos et al } \\
\text { (1987) }\end{array}$ \\
\hline CPSpher C18 & $\begin{array}{l}\text { a) } 0.01 \mathrm{M}-\mathrm{Na} \text { heptano- } \\
\text { sulfonate, } \\
0.01 \mathrm{M}-\mathrm{K} \text {-phosphate, } \mathrm{pH} 3 \\
\text { b) methanol } \mathrm{OCH}_{3} \mathrm{CN}\end{array}$ & $\begin{array}{l}215 \mathrm{~nm} \\
265 \mathrm{~nm}\end{array}$ & $\begin{array}{c}\text { Reversed } \\
\text { phase }\end{array}$ & $\begin{array}{l}\text { Aromatic amino } \\
\text { acids and their } \\
\text { amines }\end{array}$ & & $\begin{array}{l}\text { Van Boeckel } \\
\text { and Arentsen } \\
\text { Stasse } \\
(1987)\end{array}$ \\
\hline
\end{tabular}




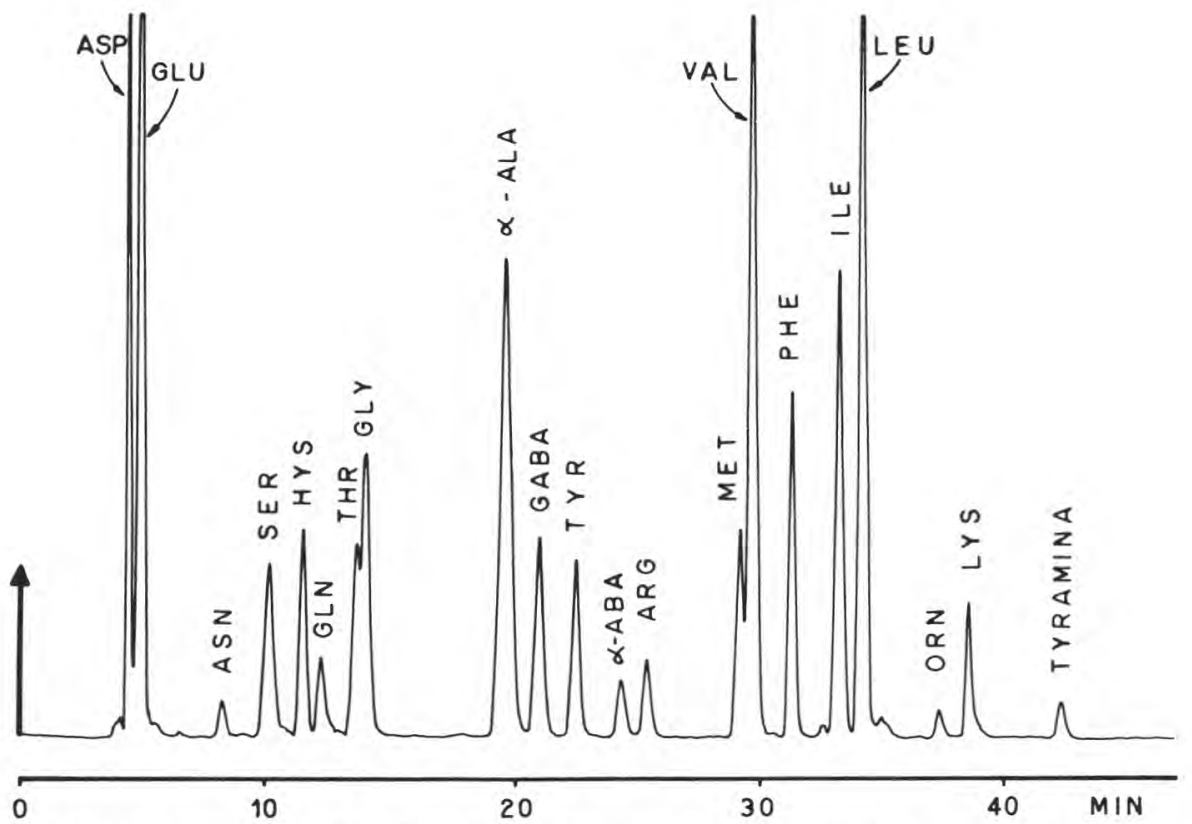

Fig 3. Chromatogram of OPA-amino acids of cheese. Column: Radial Pak C-18, $10 \mu \mathrm{m}$. Eluent A) Methanol: $10 \mathrm{mmol}^{-1}$ sodium phosphate buffer, $\mathrm{pH} 7.3$; tetrahydrofurane (19:80:1). Eluent B) Methanol: $10 \mathrm{mmol}-\mathrm{I}^{-1}$ sodium phosphate buffer, $\mathrm{pH} 7.3(80: 20)$ Lineal gradient : $0 \mathrm{~min}(0 \% \mathrm{~B}, 1.5 \mathrm{ml} / \mathrm{min}) ; 6$ $\min (15 \%$ B, $1.5 \mathrm{ml} / \mathrm{min}) ; 11 \mathrm{~min}$ (15\% B, $1.5 \mathrm{ml} / \mathrm{min}) ; 16 \mathrm{~min}$ (30\% B, $1.5 \mathrm{ml} / \mathrm{min}) ; 20 \mathrm{~min}(40 \% \mathrm{~B}, 1.5$ $\mathrm{ml} / \mathrm{min}) ; 32 \mathrm{~min}(80 \% \mathrm{~B}, 1.3 \mathrm{ml} / \mathrm{min}) ; 38 \mathrm{~min}(80 \% \mathrm{~B}, 1.3 \mathrm{ml} / \mathrm{min})$. Fluorescence detection ( $\lambda$ exc $=340$ $\mathrm{nm}, \lambda \mathrm{em}=425 \mathrm{~nm})$.

Chromatogramme des OPA-acides aminés d'un fromage. Colonne : Radial Pak C-18, $10 \mu \mathrm{m}$. Phase mobile A) Méthanol : phosphate de sodium $10 \mathrm{mmol}^{-1}, \mathrm{pH} \mathrm{7,3:tétrahydrofuranne} \mathrm{(19:80:1)} \mathrm{Phase}$ mobile B) Méthanol : phosphate de sodium $10 \mathrm{mmol}^{-1}$, $\mathrm{pH} 7,3$ (80:20) Gradient linéaire : 0 min (0\% $B, 1,5 \mathrm{ml} / \mathrm{min}) ; 6 \mathrm{~min}(15 \%$ B, 1,5 ml/min); $11 \mathrm{~min}(15 \%$ B, 1,5 ml/min); $16 \mathrm{~min}$ (30\% B, 1,5 ml/min); 20 $\min (40 \%$ B, 1,5 ml/min); $32 \mathrm{~min}$ ( $80 \%$ B, 1,3 ml/min); $38 \mathrm{~min}$ (80\% B, 1,3 ml/min). Detection par fluorescence $(\lambda e x c=340 \mathrm{~nm}, \lambda e m=425 \mathrm{~nm})$.

Reuvers et al (1986) put forward a faster method of separating tyramine in cheese: detection was achieved by measuring fluorescence after postcolumn reaction with orthophthaldehyde. Orthophthaldehyde was also used in an automatic derivative formation system prior to chromatographic separation, to determine the tyramine and histamine contents, together with the free amino acids, in cheese (Ramos et al, 1987; Fernández-García et al, 1988).

An unusual method for detecting amines was proposed by Joosten and Olieman (1986), using ninhydrin contained in the eluate itself as the derivatizing reagent and detecting the derivatives so formed at $546 \mathrm{~nm}$. 


\section{CONCLUDING REMARKS}

Taking into account the latest works published concerning the study of nitrogen compounds of dairy products, it can be concluded that HPLC and FPLC are gradually acquiring a very important role.

Although a great variety of chromatographic methods have been used for the study of nitrogen compounds, some of them present several advantages over the rest. lon-exchange chromatography is the technique which gives the best protein separations. By this technique, it is possible to quantify the casein fractions and to identify some of the genetic variants of caseins ( $\mathrm{K}$ and $\beta$-caseins) and whey proteins. Reversed phase chromatography has also been used to separate the genetic variants of whey proteins $(\beta-\mathrm{lg})$.

Gel permeation chromatography and reversed phase chromatography with wide pore columns, allow the separation of large peptides. The separation of small peptides is carried out using conventional reversed-phase columns.

Separation of amino acids is usually carried out by HPLC using reversed-phase columns. The detection of amino acids requires the preparation of derivatives detectable by ultraviolet and fluorescent techniques. Dansyl chloride and orthophthaldehyde are the most commonly used derivatizing reagents. However, these compounds present some problems and will probably be substituted by other reagents in the near future.

\section{ACKNOWLEDGMENTS}

This work has been supported by Comision Interministerial de Ciencia y Tecnología (Projects $n^{\circ}$ Ali-88-0299).

\section{REFERENCES}

American Dry Milk Institute (1971) Standards for grades of dry milk including methods of analysis. Bulletin 916

Andrews AT (1981) Electrophoresis: Theory, Techniques and Biochemical and Clinical Applications. Oxford University Press, Oxford

Andrews AT, Taylor MD, Owen AJ (1985) Rapid analysis of bovine milk proteins by fast protein liquid chromatography. J Chromatogr $348,177-185$

Antila $P$, Antila V, Mattila J, Hakkarainen $H$ (1984) Biogenic amines in Cheese. 1. Determination of biogenic amines in Finnish cheese using high performance liquid chromatography. Milchwissenschaft 39, 81-85

Aschaffenburg R, Michalak W (1968) Simultaneous phenotyping procedure for milk proteins. Improved resolution of the $\beta$-lactoglobulins. $J$ Dairy Sci 51, 1849

Barrefors P, Ekstrand B, Fägerstam L, LarssonRaznikiewicz M, Schaar J, Steffner P (1985) Fast protein liquid chromatography (FPLC) of bovine caseins. Milchwissenschaft 40, 257260

Bican P (1985) The application of the highperformance ion-exchange chromatography for the analysis of bovine milk proteins. Experientia 41, 958-960

Bican P, Blanc B (1982) Milk protein analysis- a high-performance chromatography study. Milchwissenschaft 37, 592-593

Carles C, Ribadeau Dumas B (1986) Determination of gradient elution conditions for the separation of peptide mixtures by reversedphase high-performance liquid chromatography: bovine $\beta$-casein tryptic digest. $J$ Dairy Res 53, 595-600

Champion HM, Stanley DW (1982) HPLC separation of bitter peptides from Cheddar cheese. Can Inst Food Sci Technol J 15, 283-288

Chang SF, Ayres JW, Sandine WE (1985) Analysis of cheese for histamine, tyramine, tryptamine, histidine, tyrosine and tryptophane. $J$ Dairy Sci 68, 2840-2846

Chaplin LC (1986) Hydrophobic interaction fast protein liquid chromatography of milk proteins. J Chromatogr 363, 329-335 
Dalgleish DG (1985) Glycosylated k-caseins and the sizes of bovine casein micelles. Analysis of the different forms of k-casein. Biochem Biophys Acta 830, 213-215

Davies DT, Law AJR (1987) Quantitative fractionation of casein mixtures by fast protein liquid chromatography. J Dairy Res 54,369 376

De Frutos M, Méndez E, Diez-Masa JC, Dabrio MV, Ramos M (1987) Separación de proteínas lácteas por cromatografía de líquidos de alta eficacia en fase inversa. In Resumenes de la 4as Jornadas de Analisis Instrumenta/ Barcelona, 9-11 Noviembre, 82

De Frutos M, Diez-Masa JC, Dabrio MV (1988) Separación de proteínas de suero lácteo mediante cromatografía de líquidos de interacción hidrofoba (HIC). In: Resúmenes de la XXII Reunión Bienal de la Real Sociedad Española de Química, Murcia, 26-30 Septiembre, 69

De Vilder J, Van Renterghem R, Waes G (1988) Determination of rennet whey in sour cream and buttermilk. Milchwissenschaft 43, 426429

Dimenna GP, Segall HJ (1981) Highperformance gel-permeation chromatography of bovine skim milk proteins. J Liq Chromatogr 4, 639-649

Diosady LL, Bergen I, Harwalkar VR (1980) High-performance liquid chromatography of whey proteins. Milchwissenschaft 35, 671674

Dumay E, Cheftel JC (1989) Chauffage d'un concentré protéique de $\beta$-lactoglobuline en milieu faiblement alcalin. Effets sur la solubilité et le comportement chromatographique de la $\beta$-lactoglobuline et de l' $\alpha$-lactalbumine. Sci Aliments 9, 561-582

Ekstrand B, Björck L (1986) Fast protein liquid chromatography of antibacterial components in milk. Lactoperoxidase, lactoferrin and lysozyme. J Chromatogr 358, 429-433

Fernández-García E, Ramos M, Polo C, Juárez M, Olano A (1988) Enzyme accelerated ripening of Spanish hard cheese. Food Chem 28, 63-80

Gonzales-Llano D (1989) Caracteristicas físicoquímicas y sensoriales del queso de Gamonedo. Evolución de los diferentes componentes a lo largo de la maduración. Tesis Doctoral Universidad Complutense. Madrid
Gonzalez-Llano D, Polo C, Ramos M (1987a) Estudio de los péptidos de bajo peso molecular de quesos azules, por HPLC. In: Resumenes de las 4as Jornadas de Análisis Instrumental Barcelona, 9-11 Noviembre, 72

Gonzales-Llano D, Ramos M, Polo C (1987b) Gel filtration and high-performance liquid chromatographic analysis of phosphotungstic acid soluble peptides from blue cheese. Chromatographia 23, 764-766

Guillou H, Miranda G, Pelissier JP (1987) Analyse quantítative des caséines dans le lait de vache par chromatographie liquide rapide d'échange d'ions (FPLC). Lait 67, 135-148

Gupta BB (1983) Determination of native and denatured milk proteins by high-performance size exclusion chromatography. $J$ Chromatogr 282, 463-475

Haasnoot W, Venema DP, Elenbaas HL (1986a) Determination of cow milk in the milk and cheese of ewes and goats by fast protein liquid chromatography. Milchwissenschaft 41. 642-645

Haasnoot W, Elenbaas HL, Venema DP (1986b) Applications of fast protein liquid chromatography in food control. In: Proceedings Second FPLCB Symposium, (Pharmacia, ed) Utrecht September, 15-25

Haasnoot W, Venema DP, Elenbaas HL (1987) A preliminary study to determine the extent of proteolysis in Gouda cheese using fast protein liquid chromatography on various stationary phases. In: Rapid Analysis in Food Processing and Food Control (Proceedings of Fourth European Conference on Food Chemistry) 1-4 June, Loen, Norway 1, 71-76

Hill AR, Manji B, Kakuda Y, Myers C, Irvine DM (1987) Quantification and characterization of whey protein fractions separated by anion exchange chromatography. Milchwissenschaft 42, 693-696

Humphrey RS, Newsome LJ (1984) Highperformance ion-exchange chromatography of the major bovine milk proteins. NZJ Dairy Sci Technol 19, 197-204

Joosten HMLJ, Olieman C (1986) Determination of biogenic amines in cheese and some other food products by high-performance liquid chromatography in combination with thermosensitized reaction detection. J Chromatogr $356,311-319$ 
Kaiser KP, Krause I (1985) Analytik von Proteinen in Lebensmitteln mit elektrophoretischen und chromatographischen Verfahren. $Z$ Lebensm Unters Forsch 180, 181-201

Kaminogawa S, Yan TR, Azuma N, Yamauchy $K$ (1986) Identification of low molecular weight peptides in Gouda-type cheese and evidence for the formation of these peptides from $23 \mathrm{~N}$-teminal residues of $\alpha_{\mathrm{s} 1}$-casein by proteinases of Streptococcus cremoris $\mathrm{H} 61$. J Food Sci 51, 1253-1256

Kim YA, Chism GW, Mangino ME (1987) Determination of the beta-lactoglobulin, alphalactalbumin and bovine serum albumin of whey protein concentrates and their relationship to protein functionality. J Food Sci 52 , 124-127

Kneifel W, Ulberth F (1985) Zur Methodik der Hitzeklssifizierung von Magermilchpulver unter Berücksichtigung der HPLC-Analyse. Milchwissenschaft 40, 265-269

Leadbeater L, Bruce-Ward F (1987) Analysis of tryptic digests of bovine $\beta$-casein by reversed phase high-performance liquid chromatography. J Chromatogr 397, 435-443

Lemieux L, Amiot J (1989) Application of reversed-phase high-performance liquid chromatography to the separation of peptides from phosphorylated and dephosphorylated casein hydrolysates. I Chromatogr 473, 189-206

Manji B, Kakuda Y (1986) Thermal denaturation of whey proteins in skim milk. Can Inst Food Sci Technol J 19, 163-166

McKenzie HA (1971) In: Milk Proteins: Chemistry and Molecular Biology (McKenzie HA, ed) Academic Press, New York 11, 258-266

Mellander O (1939) Elektrophoretische Untersuchung von Casein. Biochem Z 300, 240245 (from Guillou et al, 1987)

Mercier JC, Maubois JL, Poznanski S, Ribadeau Dumas B (1968) Fractionnement préparatif des caséines de vache et de brebis par chromatographie sur DEAE cellulose, en milieu urée et 2-mercaptoéthanol. Bull Soc Chem Biol 50, 521-530

Mikkelsen J, Hojrup P, Knudsen J (1987) Purification of goats milk casein by reversedphase high-performance liquid chromatography and identification of $\alpha_{\mathrm{s} 1}$-casein. J Dairy Res 54, 361-367
Monnet V, Le Bars D, Gripon JC (1986) Specificity of a cell wall proteinase from Streptococcus lactis NCDO-763 towards bovine $\beta$ casein. FEMS Microbiol Lett 36, 127-131

Morr CV, Seo A (1988) Fractionation and characterization of glycomacropeptide from caseinate and skim milk hydrolysates. J Food Sci $53,80-87$

Mottar J, Van Renterghem R, De Vilder J (1985) Evaluation of the raw material for UHT milk by determining the degree of protein breakdown through HPLC. Milchwissenschaft 40, 717-721

Murphy BF, Mulvihill DM (1988) Proteins recovered from acid whey/skim milk mixtures heated at alkaline $\mathrm{pH}$ values. J Soc Dairy Technol 41, 22-26

Olieman C, Van Den Bedem JW (1983) A sensitive HPLC method of detecting and estimating rennet whey total solids in skim milk powder. Neth Milk Dairy J 37, 27-36

Olieman C, Van Riel JAM (1989) Detection of rennet whey solids in skim milk powder and buttermilk powder with reversed-phase HPLC. Neth Milk Dairy J 43, 171-184

Park SS, Kim KS, Kim YJ, Kim YK (1980) Studies on cheese ripening. VI. Changes in water soluble nitrogenous compounds during the ripening of Cheddar cheese. Korean J Anim Sci 20, 200-204

Pearce RJ (1983) Analysis of whey proteins by high performance liquid chromatography. Aust J Dairy Technol 38, 114-117

Pham AM, Nakai S (1984) Application of stepwise discriminant analysis to high pressure liquid chromatography profiles of water extract for judging ripening of Cheddar cheese. J Dairy Sci 67, 1390-1396

Polo C, Ramos M, Sanchez R (1985) Free aminoacids by high performance liquid chromatography and peptides by gel electrophoresis in Mahon cheese during ripening. Food Chem 16, 85-96

Ramos M, Caceres I, Polo C, Alonso L, Juarez $M$ (1987) Effect of freezing on soluble nitrogen fraction of Cabrales cheese. Food Chem 24, 271-278

Reuvers TBA, Martin De Pozuelo M, Ramos M, Jimenez R (1986) A rapid ion-pair HPLC procedure for the determination of tyramine in dairy products. J Food Sci 51, 82-84 
Schlossberger (1846) Vorläufige Notiz über einige aus dem sogenannten. Casein erhaltenen substanzen. Justus Liebigs Ann Chem 58, 92-95 (from Guillou et al, 1987)

Shimizu M, Lee SW, Kaminogawa S, Yamauchy $\mathrm{K}$ (1986) Functional properties of a peptide of 23 residues purified from the peptic hydrolyzate of $\alpha_{\mathrm{s} 1}$-casein: changes in the emulsifying activity during purification of the peptide. J Food Sci 51, 1248-1252

Tobler M, Windemann H, Baumgartner E (1983) HPLC-Auftrennung von Peptiden aus Casein von Kuh- und Ziegenkäse. Mitt Gebiete Lebensm Hyg 74, 132-139

Trieu-Cuot P, Gripon RL (1981) Electrofocusing and two-dimensional electrophoresis of bovine caseins. J Dairy Res 48, 303-310

Van Den Bedem JW, Leenheer J (1988) Heat treatment classification of low heat and extra low heat skim milk powder by HPLC. Neth Milk Dairy J 42, 345-350

Van Boekel MAJS, Arentsen-Stasse AP (1987) Determination of aromatic biogenic amines and their precursors in cheese by high- performance liquid chromatography. $J$ Chromatogr 389, 267-272

Van Hooydonk ACM, Olieman C (1982) A rapid and sensitive high-performance liquid chromatography method of following the action of chymosin in milk. Neth Milk Dairy J 36, 153158

Visser S, Slangen KJ, Rollema HS (1986) Highperformance liquid chromatography of bovine caseins with the application of various stationary phases. Milchwissenschaft 41, 559-562

Wake RG, Baldwin RL (1961) Analysis of casein fractions by zone electrophoresis in concentrated urea. Biochem Biophys Acta 47, 225239

Waugh RG, Von Hippel PH (1956) K-casein and the stabilization of casein micelles. $J A m$ Chem Soc 78, 4576-4582

Windemann H, Tobler M, Baumgartner E (1986) Vergleich der Polyacrylamidgelelektrophorese von Caseinen und HPLC-Auftrennung der tryptisch abgebauten Caseine von verschiedenen Milch- und Käsearten. Mitt Gebiete Lebensm Hyg 77, 565-582 